\title{
Osmanlı İlk Dönemi Medreselerinin Kuruluş Süreci ve Arap Dilinin Öğretimi
}

Hüseyin DEMİR, Yrd. Doç. Dr., Bartın Üniversitesi Edebiyat Fakültesi, hudemir@bartin.edu.tr

Öz: Osmanlı İmparatorluğu; aşiretten beyliğe, beylikten devlete, devletten ise cihan imparatorluğuna geçerken, kurumsallaşma döneminin en önemli ve öne çıkmış eğitim kurumlardan biri olan medreselerde eğitim ve öğretimin Arap Dili'nde yapılmasını sağlamış ve böylece kendine has bir eğitim ve öğretim sistemi oluşturmuştur. Bununla birlikte Osmanlı İmparatorluğu'nun bilime ve bilim adamlarına önem vermesi, eğitim ve öğretim kurumlarını parasız yapması ve bu kurumlarda eğitim öğretim faaliyetlerini yerine getiren öğrencilerin barınma intiyaclarını karşılaması, Osmanlı toplumunu eğitim ve öğretime teşvik ederken, ilim hayatının kısa süre içerisinde ilerlemesini ve yaygınlaşmasını sağlamıştır. Bu bağlamda o dönemin eğitim kurumları olan medreselerde okutulan Arap Dili, genellikle nakli ilimlerden oluşan Kur'an tefsiri, Hadis ve İslam fıkhı gibi dini eğitime yönelik olmuşsada i̇stanbul'un fethinden sonra akli ilimlerin verilmesi ve tahsili için öğrenilmesi zorunlu olan bir dile dönüşmüştür. Bununla beraber eğitim ve öğretimin yenilenmesi eğitim kurumları olan medreselerde eğitim düzeyini yükseltmiş, medreselerin gelişmesini sağlamış ve sayılarını arttırmışır. Bu medreselerde okutulan ilmi eserler ve onlara kaynak teşkil eden kitaplar, Arap dilinde yazıımışır. Bu durum Arap Dili'nin öğrenilmesi ve öğretilmesini kaçınılmaz kıımıştır. İşte bu çalışmada; Osmanlı medreselerinde, eğitim ve öğretim dili olan Arapça'nın, öğretiminin hem medreselerin yapısı hem de eğitim-öğretim metodlarına değinmek suretiyle nasıl ve hangi boyutlarda yapıldığına dair tespitlerde bulunmaya çalışık.

Anahtar Kelimeler: Osmanlı İmparatorluğu, medrese, arap dili öğretimi, arapça gramer kitapları

\section{The Establishment Process of the Ottoman First Period Madrasas and the Teaching of Arabic Language}

\begin{abstract}
Madrasas which were one of the most important and famous educational establishments of the Ottoman Empire in the transitional period from a tribe to a principality, from a principality to a state, from a state to a world empire made education and training possible in Arabic language and in this way formed a special education and training system. The fact that Ottoman Empire attached importance to scientific issues and scientists, the educational establishments were then free, the need of pupils for sheltering was met enabled scientific life to advance and become popular in a short span of time as well as encouraging the Ottoman society in terms of education and training. In this context, Arabic which was taught in madrasas turned into a compulsory language for the purpose of training pupils in fundamental Islamic sciences for religious education. Fundamental Islamic sciences are generally composed of interpretation of the Koran, the prophet Muhammad's sayings/deeds and Islamic law. Arabic was also compulsory in madrasas to teach rational sciences after the conquest of Istanbul. Besides, the innovation of the education and learning system raised education levels of madrasas, enabled them to advance and increased their numbers. Scientific works and reference books were written in Arabic language. This situation made teaching and learning of this language indispensable. In this study, we touched upon the educative structure of Madrasas and teaching-training methods. In doing so we also tried to detect how and in what dimensions the Arabic language which was the language of the education and training in Ottoman madrasas were taught.
\end{abstract}

Key Words: Ottoman Empire, madrasa, arabic language, arabic grammar books. 


\section{GíRiş}

İslam dünyasında ilk eğitim ve öğretim kurumu olarak tarihte yerini alan SuffaMedresesi, Mescidi Nebevi'nin yanına bizzat Hz. Peygamber tarafından inşa edilmiş ve o zamanın en önemli eğitim öğretim müessesi haline gelmiştir. Burası; yetişkin insanlara dini eğitimlerinin verildiği bir okul olmanın yanı sıra, kalacak yerleri olmayanların da barınağı haline gelmiştir. Daha sonra i̇slami ilimlerin belli bir kural düzeninde tertiplenip, ibadet yerlerinin dışında yeni eğitim müesseselerinin açılması ve böylece öğrencilere daha verimli bir eğitimin verilmesi sağlanmıştır. İslam'ı seçen Türk devletleri, Kuran-ı Kerim'in emir ve yasaklarını benimseyip, dinin emirlerini hem öğrenmeye hem öğretmeye hem de tatbik etmeye gayret etmiştir. Bu noktada Müslüman Türklerin kurduğu en güçlü i̇slam devletlerinden olan Osmanlı Imparatorluğu karşımıza çıkmaktadır. Çünkü bu devlet, Islam dinini öğretmek, emir ve yasaklarını anlama, anlatma ve hayata uyarlama noktasında, topluma rehberlik etmesi ve toplumun ihtiyacı olan eğitim ve öğretim faaliyetlerini yürütmesi için medreseler kurmuş ve bu medreselerde Arap dili öğretiminin gerçekleştirilmesine son derece önem vermiştir. Zira İslami ilimleri öğrenebilmek ancak Arapça'ya en iyi bir şekilde vakıf olmayı gerektirdiğinden, Arapçanın öğretiminde belirlenen kaynak eserleri bir ders programı altında medreselerde uygulamaya koymuştur.

\section{Osmanlı Öncesi Medreseler}

Eğitim ve öğretimin gerçekleştirildiği cami ve mescitlerin dışında kendi başına kurulan ilmi müesseseler olarak görülen medreselerin varlığına, IX. yüzyılda İslamiyet'i kabul eden ilk Türk devleti olan Karahanlılar zamanında şahit oluyoruz. Daha sonraki dönemde ise Büyük Selçuklu Devleti, medrese kurumlarının sadece teşkilatlanmasını değil aynı zamanda hem ilmin genişleyip yayılmasını sağlamak hem de ders veren öğretmenlere maaş bağlayarak, bunu bir gelenek haline getirip memleketin her tarafında bu gibi ilmi kurumların açılmasına önderlik yapmıştır (Baltacı, 1976; Doğan, 1997).

Büyük Selçuklu medreselerini, kendilerine gerek yapısal gerekse de teşkilatıyla örnek alan Anadolu Selçukluları ve Anadolu'ya yerleşen birçok Türkmen beyleri ise, halkın eğitim ve öğretimine ve bu eğitim kurumlarının en güzel bir şekilde genişleyip yaygınlaşmasına önem vererek halkın okur-yazarlığını arttırmaya çalışmışlardır. Osmanlı öncesi bu medreselerde, herhangi bir resmi derecelendirme görülmeyip bilakis eğitimcilerin ilmi kabiliyetlerine göre şöhret bulmaları sağlanmış, temel eğitimini alan öğrencilerin daha sonra hangi dalda uzman olmak isterlerse, o ilim dalında tanınmış eğitimcilere giderek ders görüp mezun olmaları sağlanmıştır (ihsanoğlu, 1998).

Ayrıca halka açık olan bu medreselerin yanında uzmanlaşmak isteyenler için de başka medreseler kurulmuştur. Hukuk için Konya'da, tıp için Kayseri, Çankırı ve Sivas'ta, astronomi için ise, Kütahya ve Kırşehir'de kurulan hususi medreseler bunlara örnek olarak verilebilir. Selçuklular zamanındaki bu uzmanlaşma, Osmanlılar devrinde ise olgunlaşarak sürekliliğini devam ettirmiştir (Sevinç, 1991).

\section{Osmanlı Medreseleri}

Selçuklu Devletin'de olduğu gibi Osmanlı Devleti de, hâkim olduğu topraklarda eğitim ve ögretimi genellikle cami ve mescitlerde gerçekleştirmiştir. Orhan Bey (1324-1362) döneminden itibaren ise, eğitim ve ögretim faaliyetleri ilk olarak İnik şehrinde kurulan medreselerde gerçekleştirilmeye başlanmıştır (Aşıkpaşazade, 1332).

Siyasi ve ekonomik nedenlerle göçe mecbur bırakılan şöhret bulmuş ilim sahibi kişiler Anadolu'ya yerleşip Orhan Bey tarafından yeni yaptırılan medreselerde eğitimci olarak istihdam ediliyordu. Bu kişilerin medreselerde ders vermelerinden dolayı hem İznik şehrinin hem de medreselerin önemi ve şöhreti artıyordu (Adıvar, 1943).

Bununla birlikte Osmanlı sultanları ve bunları örnek alan diğer Osmanlı yöneticileri de hızlı bir şekilde Anadolu'nun her bir yerine kendi imkânları dâhilinde eğitim kurumları olan medreselerin inşasını gerçekleştirerek halkın eğitim ve öğretimine katkı sağlamışlardır (Tahir 
Mehmet, 1333). Zamanla kurulan bu yeni medreselere Anadolu'dan ve İslam memleketlerinden tanınmış eğitmenler davet edilmiş ve bu medreselerde ders vermeleri sağlanmıştır (İnalcık, 1973).

Eğitim ve öğretimin sağlandığı medreseler, zaman içinde her tarafa yayılmış ve ilköğretim üstündeki değişik eğitim kademelerini temsil etmiştir. Bununla birlikte Osmanlı İmparatorluğu'nun ilme ve ilim adamlarına önem vermesi, eğitim kurumlarının parasız olması ve öğrencilerin barınma ihtiyacını karşılaması Osmanlı toplumunu eğitim ve öğretime teşvik ederken ilim hayatının kısa süre içerisinde ilerlemesini ve yaygınlaşmasını sağlamıştır (Saray, 1987).

\section{Osmanlı Medreselerinin Teşkilatlanması}

Osmanlı Devleti'nde eğitim ve bilim hayatının çok hızlı bir şekilde ilerlemesi ve medrese kurumlarının sayısının artmasıyla, özellikle bu medreselerin kendi aralarında bir derecelendirilme ihtiyacı ortaya çıkmıştır. Osmanlı medreseleri birinci olarak Sultan I. Beyazıt (1389-1402) zamanında bir sisteme kavuşturulmuş, daha sonra da Sultan II. Murad'ın (14211451) devrinde medreseler hakkında ilk teşkilat kanunları hazırlanmıştır (Uzunçarşııı, 1965). Osmanlı medreselerindeki asıl teşkilatlanma ise, ancak Fatih Sultan Mehmet (1451-1481) zamanında inşası tamamlanan Sahn-ı Semân medreselerinin kurulmasından sonra olmuştur (Karakök, 2013).

Daha sonra Kanuni Sultan Süleyman (1520-1566) zamanında Sahn-ı Süleymaniye medreselerinin kurulması ile medreselerin kendi eğitimsel kuralları çerçevesinde değişim ve gelişimi sağlanmıştır. Böylece üçüncü defa teşkilatlandırılan medreseler, en ileri seviyedeki eğitim ve öğretim müesseseleri olarak tarihteki yerini almıştır (Tekindağ, 1973).

\section{Osmanlı Medreselerinin Türleri}

Halkın eğitim ve öğretimine önem veren Osmanlı Devleti, inşa ettiği yeni medreseleri bireysel ve toplumsal işleve yönelik iki grupta; genel ve ihtisas medreseleri olarak düzenlemiştir (Baltacl, 1976; Karakök, 2013).

Genel medreseler, genellikle Osmanlı Devlet'inde Tecrid (yirmili), ${ }^{1}$ Miftâh (otuzlu), ${ }^{2}$ Kırklı, ${ }^{3}$ Hariç ve Dâhil Ellili ${ }^{4}$, Sahn-ı Semân ${ }^{5}$ ve Sahn-ı Süleymaniye medreseleri ${ }^{6}$ olarak isimlendirilirdi. İhtisas medreseleri ise, Daru'I-Kurra, ${ }^{7}$ Daru' $^{\prime}$--Hadis ${ }^{8}$, Daru'ş-Şifa medreseleri ${ }^{9}$ adı altında bilinmekteydi (Doğan, 1997; Demir, 2005; Hızlı, 2008).

Osmanlı medreseleri, Sultan II. Murad'ın (1421-1451) Edirne ve Bursa şehirlerinde inşa ettirmiş olduğu medreselerle eğitim ve öğretimde yükselişi, Fatih Sultan Mehmet'in kurmuş olduğu Sahn-ı Semân medreseleri ile de zirveyi yaşamıştır. Daha sonra Kanuni Sultan

\footnotetext{
${ }^{1}$ Bu medreseler, İslam inanç esaslarını kaleme alan Seyyid Ali b. Muhammed el-Cürcani (ö. 1413)' nin Hâşiye-i Tecrid adlı eserinin okutulması veya öğreticilerin günlük olarak aldıkları 20 - 25 akçe ücret karşılığı nedeniyle böyle isimlendirilmiştir (Faroqhi, 1973; İnalcık, 1973; Brockelmann, 1943-1949).

2 Bu medreseler, Belâgat ilmine ait Telhīsu'l-Miftâh adlı esere bir şerh yazan Sa'duddin Mesud b. Ömer et-Taftazani (ö. 1398)'nin eseri olan Şerh-i Miftâh adlı kitabın okutulması veya öğretmenlerin günlük yevmiyeleri olan 30-35 akçe ücret karşılığı nedeniyle böyle isimlendirilmiştir (İnalcık, 1973; Brockelmann, 1943-1949).

${ }^{3}$ Fıkıh usulü üzerine Sadrüşşeria es-Sani Übeydullah b. Mesud (ö. 1346) 'un et-Tenkih kitabın şerhi olan et-Tavzih adlı esere, Sa'duddin Mesud b. Ömer et-Taftaza'nin açıklayıcı et-Telvih adlı kitabını yazmış ve bu eserin bu medreselerde okutulması veya müderrislerin 40 akçe günlük ücret karşılığı sebebiyle böyle isimlendirilmiştir (Özen, 2008; İnalcık, 1973; Brockelmann, 1943-1949). ${ }^{4}$ Hariç Ellili medreseler, eğitmenlerin günlük 50 akçe ücret aldıklarından bu ad ile isimlendirilmiştir. Dâhil Ellili medreselerde de eğitimciler, Hariç Ellili medreseler de olduğu gibi günlük 50 akçe almaktaydı, ondan farkı, sadece bu gibi medreseleri her zaman Osmanlı saray halkının inşa etmiş olmasıydı (Hızlı, 1998; Yakuboğlu, 2006).

${ }^{5}$ Fatih sultan Mehmet'in İstanbul şehrinin fethinden sonra Fatih semtinde kurduğu sekiz bölümden oluşan en üst düzeyde hem nakli hem de akli bilimlerin verildiği bir yükseköğrenim kurumudur (bkz. Demir 2005; krş. Kunter, Ülgen 1938).

${ }^{6}$ Kanuni Sultan Süleyman'ın İstanbul Süleymaniye semtinde kurmuş olduğu külliye içerisinde yer alan medreselerdir (bkz. Demir 2005).

${ }^{7}$ Kur'an-ı Kerimi en güzel yöntem biçimleriyle öğretip okumayı sağlayan ve ezberlenmesinin gerçekleştirildiği kurumlardır (bkz. Demir 2005).

${ }^{8}$ Derece bakımından en yüksek medreseleri teşkil eden bu kurumlarda meşhur Hadis kitapların öğretildiği ve eğitim verenlerin günlük yüz akçe aldığı kurumlardır (bkz. Demir 2005).

${ }^{9}$ Bu medreseler, tıp eğitim ve öğretimin sağlandığı kurumlardır (bkz. Demir 2005).
} 
Süleyman'ın (1520-1566) Sahn-ı Süleymaniye medreselerini kurmasıyla birlikte Osmanlı medreseleri eğitim ve öğretimde en doruk noktasına çıkmıştır. XVI. yüzyılın sonları ise, bu medreselerin gerilediği dönem olarak görülmüştür (Eliaçık, 2014).

\section{Osmanlı Medreselerinde Öğrenim Gören Öğrenciler}

Osmanlı toplumunda çocuklar 5 veya 6 yaşlarına geldikleri vakit aileleri tarafından ilk mektep olarak görülen sıbyan okullarına verilirlerdi. Bu okullara, önceden sadece erkekler alınırken kız çocuklarında Osmanlı zamanında eğitim ve öğretimden faydalandığı ve zamanla hem erkek hem de kız çocukların eğitim gördüğü birer sıbyan mekteplerinin de kurulduğu görülmüştür (Baltacı, 1976; Doğan, 1997).

Daha sonra ise, merkezi yönetimin ve vakıfnamelerde belirtilen şartlar esas alınarak 1430 yaş arası erkekler, eğitimlerini bir üst kademe olarak görülen medreselerde devam ettirebilirken; kız öğrencilerin ise, ne öğrenci ne de öğretici olarak medrese kurumlarında devam etmelerine izin verilmemiştir (Akgündüz, 1997).

Medrese eğitimini başarı ile tamamlayan öğrenciler icâzetnâme denilen bir diploma alarak, bir üst medresede eğitim ve öğretim görme hakkı elde ederlerdi (Doğan, 1997). Yüksek eğitimlerini medreselerde devam ettirme hakkı kazanan öğrencilerden; eğitimlerinin başlangıcından itibaren mezun olacakları vakte kadar yatılı kalmalarıyla beraber hem para yardımı hem de yiyecek masraflarının karşılandığı ve öğrencilerden sadece zamanında derslere katılmaları ve çalışmaları, ahlaksız davranışların içine girmemeleri istenmekteydi (Hızlı, 1998).

\section{Osmanlı Medreselerinde Arap Dili Öğretimi}

Edebi ve ilmi eserler çoğunlukla Selçuklular zamanında Farsça ve Türkçe dillerinde kaleme alınmış olup, bunun yanında sultanların ve halkın iletişim için kullandığı dil ise Türkçedir. Sultanların Türkçe diline gösterdikleri rağbet ve bunun bir sonucu olarak dönemin önde gelen ilim erbaplarının bazı eserlerini Türkçe'ye tercüme etmek istemeleri, Selçuklu coğrafyasında eğitim ve öğretim faaliyetlerinin gerçekleştirildiği medreselerde hem konuşma hem de eğitim öğretim dili olarak Türkçe ön plana çıkması açısından büyük önem arz etmiştir (Kut, 1998). Ancak, Osmanlı medreselerinde okutulan eserlerin yazıldığı dilin, genellikle Arapça olması, bu eserleri anlamayı kolaylaştırması için öğrenim ve öğretimde verilen dil eğitimi içerisinde bu dilin öğretilmesini zaruri kılmıştır. Bu nedenle, medrese öğrencilerinin Arapçayı öğrenmek için yoğun çaba sarf ettikleri görülmekteydi (Bilge, 1984).

Medreselerde verilen derslerin açıklamaları Türkçe yapılıyorken; öğrenci, ders esnasında bu açıklamalara ilaveten aldığı notları veya öğrendiği yeni bilgileri, kitaplarının yan taraflarına veya kendisinin getirmiş olduğu defterlere, kaynaklarda tespit edilebildiği kadarıyla Arapça veya Osmanlıca olarak yazmaktaydı (Hazer, 2002).

Arapçayı öğrenmekteki asıl gaye ise hiç şüphesiz, İslami yüksek ilimler denilen ulum-u âliye (nakli ilimler) adı altında Kur'an-ı Kerim, hadis, tefsir, fıkıh, akaid, feraiz vb. ders kitaplarını okumak ve anlamaktı. Daha sonrasında ise, Fatih Sultan Mehmet ile birlikte bu ilimlerin yanına müspet ilimler olan matematik, hendese, mantık, tıp, astronomi, felsefe, kelam tarih, coğrafya, fizik gibi dersler de eklenmiştir. Bununla beraber eğitim ve öğretimin yenilenmesi medreselerde eğitim düzeyini yükseltmiş, medreselerin gelişmesini sağlamış ve sayılarını arttırmıştır (İzgi, 1997; Şanal, 2003; Hızlı, 2008; Demir, 2005).

Osmanlı medreselerinde ders veren öğretmenler, belirledikleri bir plan/müfredat içinde dersleri yürütür ve belli eserlerin okunmasını sağlardı. Öğrencilerin bir üst sınıfa geçmeye hak kazanması da belirlenen bu eserlerin öğrenci tarafından okunup, bitirilmesi ile gerçekleşirdi (Eliaçık, 2014; Hızlı, 2008).

İslami ilimlerin temel derslerine yardımcı olacak eserleri okuyup anlayabilmeyi sağlamak için gerekli görülen Arap dilbilgisine ait olan ve ulumu cüz'iye (alet ilimler) denilen kitaplar alt kademede bulunan medreselerde okutulurdu. Bu ulumu cüz'iye'ye ait sayılan ders kitaplarını okumadan yüksekokul adı altında Fatih ve Süleymaniye medreselerine girmek mümkün değildi. Çünkü Sultan Fatih'in yeni getirmiş olduğu ders programında üst kademede 
bulunan medreselerde sarf ve nahiv ilimleri okutulmuyordu. Arapça gramerine ait olan derslerin alımından sonra üst medreselerde görülecek olan diğer derslerin eğitimi ve öğretimi daha kolay hale geliyordu. Ayrıca Osmanlı medreselerindeki ders müfredatları incelendiğinde görülecektir ki, Arap edebiyatı veya tarihi gibi dersler yer almamış, sadece Arapça gramerin daha kolay anlaşılabilmesi için Arapça şiir ve edebiyat örnekleriyle konuların daha iyi bir şekilde anlaşılmasına çalışılmıştır (Hazer, 2002; Usta, 2012).

Yukarıda belirtildiği üzere medreselerde eğitim ve öğretim kapsamında ele alınan Arapçanın öğrenimi genellikle belirli kitapların okunması ile gerçekleşiyordu. Bir kitapta yer verilmeyen veya üzerinde fazla durulmayan konular onu izleyen gerekli kitaplarla telafi edilmeye çalışılıyordu. Bununla birlikte dersleri veren öğreticiler de büyük bir öneme sahipti. Kendileri öğrencilere usul olarak tümdengelim (dedüktif) bir yöntem uygulayarak hem Arapça eserleri okutmuş, manalarını açıklamış ve hem de öğrencilerin hazırlamış oldukları dersleri dinleyerek seviyelerini tespit etmiş ve onlara öğrenim süreçlerinde yardımcı olmaya çalışmışlardır (Hazer, 2002; Usta, 2012). Tabii ki tüm bunlar yapılırken, Arapça öğretiminde başvurulan yöntem ve usul ise; genellikle ezber, ${ }_{10}^{10}$ tekrar, ${ }^{11}$ yazma, ${ }^{12}$ soru-cevap, ${ }^{13}$ mütalaa, ${ }^{14}$ münazara, ${ }^{15}$ gibi metotlardı (Parladır, 1987; Şeşen, 1986; Doğan, 1997).

Osmanlı medreselerinde dini ilimlerin öğrenilebilmesi ve anlaşılabilmesi için gerekli olan Arapça dilbilgisi, Arapça kullanımında gerekli olan kelime yapılarının tahlili, cümle ve metinlerin kuralları ve belâgat içeren ifadeleri hem okuyabilme hem de anlayabilme becerelerinin kazanmasını sağlıyordu (Hazer, 2002).

Arapçada yapılan hataları giderebilmek için her zaman eğitim ve öğretim de ilk sıralarda yer alan Arap dilinin kurallarının belirleyici konumunda olan zorunlu temel Arapça gramer ders kitapları ise şunlardır;

Sarf ilmi: Kelime bilgisi ve fiil çekimlerinin öğretildiği bir ilim dalıdır. Sarf ders kitapları olarak okutulan belli başlı kitaplar ise; Emsile-i muhtelife ve muttaride, ${ }^{16}$ binấ'u l-ef'âl, ${ }^{17}$ elmaksud, ${ }^{18}$ el-izzi, ${ }^{19}$ merâhu l-ervâhh, ${ }^{20}$ eş-şâfiye ${ }^{21}$ şeklindedirler.

\footnotetext{
${ }^{10}$ Derste işlenilen konuların ya ders esnasında ya da ders dışında ezberletildiği bir yöntemdir.

${ }^{11}$ Derslerin iyice anlaşılabilmesi için derslerden sonra yardımcı öğretmen tarafından konuların öğrencilere tekrar ettirildiği bir yöntem şeklidir.

${ }^{12}$ Derste işlenen konuların öğrenciler tarafından kâğıda yazdırılma yöntemidir.

${ }^{13}$ Öğretmen ve öğrencilerin karşılıklı birbirlerine sorular sorup cevaplar alma yöntemidir.

${ }^{14}$ Öğrencilerin derse gelmeden önce işleyecekleri konuları, kendilerinin önceden çalışması ve öğretmenin karşııında anlatma yöntemidir.

${ }^{15}$ Derste işlenen konuların ayrıntılı bir şekilde üzerinde durulup anlaşılmasını sağlayan bir yöntemdir.

${ }^{16}$ Bu ders kitabında yer alan konular; Fiil ve isim kalıpları, fiillerin belirli (malum) ve belirsiz (mechul) kişi zamirlerine göre çekimi, isimlerin ve sıfatların tekil-ikil-çoğul çekimlerini gösteren bir kitapdır.

${ }^{17}$ Arapça'da görülen fiil kalıplarındaki şekil ve mana değişikliklerini içeren ve ilk 18 babda asıl kökleri üç harften oluşan (sülasi mücerred) ve aslı üç harften oluşan fiillere bir, iki veya üç harf ilave edilerek oluşan fiiller (sülasi mezid), diğer 17 babda ise asıl kökleri dört harften oluşan (rubâi mücerred) ve aslı dört harften oluşan fiillere bir veya iki harf ilave edilerek oluşan fiilleri (rubâi mezid) 35 bab adı altında inceleyen ve eserin sonunda fiillerin türlerini (aksâm-ı seb’a) anlatan bir kitaptır (Çakır, 1992).

${ }^{18}$ Bu eser sarf ilminin önemini anlatan, daha sonra sülasi ve rubai mücerred ve mezid fiillerin vezinlerini ve kalıplarını, mastar çeşitleri ve mastardan türeyen kip ve kalıpların kuruluş ve çekimleri, sahih fiillerin mücerred ve mezid kalıplarının mazi, muzari, emir ve nehiy kiplerinin geçişli (müteaddi) ve geçişsiz (lâzım) fail ve mef'ul çekimleri, geçişsiz bir fiili geçişli, geçişli bir fiili geçişsiz yapmanın yolları, hangi fiil kalıplarının geçişlilik veya geçişsizlik bildirdiği, fiil kalıplarının ifade ettiği istek, işteşlik (müşâreket) ve dönüşlülük (mutâvaat) içeren anlamlarını, isim ve fiillere ilave olan harfler açıklanmıs, illetli ve sahih fiillerden hemzeli ve muzaaf olan fillerin çekimleri esnasında meydana gelen harf değiştirilmesi (i'lâl), başka bir harfin getirilmesi (ibdâl) ve birleştirme (idğâm) gibi değişiklikleri ve kuralları açıklamaktadır (bkz. Demirayak, 2003).

${ }^{19}$ Maksud kitabından sonra sarf ilminin öğrenilmesinde dördüncü kitap olan el-izzi adlı eser, fiilleri harf sayısına ve türüne göre tasnif ederek illetli fiillerin kuraldışı durumlarını, ismi zaman ve mekan konularına yer vermektedir (bkz. Özel, 2013)

${ }^{20}$ Bu ders kitabında işlenen konular ise; mastar ve mastar kalıpları, sülasi mücerred fiillerin altı kalıbı ve bunların bazı Arap kabileleri tarafından farklı kullanıış̧ı, sülasi mezid fiillerin on iki kalıbı, rubai mücerred fiil ve ondan türeyen rubai mezid fiiller ve ona dahil edilen fiil kalıpları, Aksâmı seb'anın zamanlara ve şahıslara göre çekimleri ve çekim sırasında meydana gelen değişiklikler ele alınarak açıklanmıştır (bkz. Demirayak, 2004).

${ }^{21}$ Bu eserde tasrifin tanımı, isim ve fiil kalıpları, vezin-mevzun, mücerred-mezid kalıpları ve anlamları, daha sonra fiil ve isimlerin kalıpları ile ilgili kuralları, çoğul şekilleri, ziyade ve ilhak suretiyle eklenen harfler ve bunlara ait vezinler, kelime yapısındaki harf ve ses değişim ve dönüşümleriyle ilgili meseleler ele alınarak alıştırma ve örneklere yer verilmiştir (bkz. Kılıç, 2010).
} 
Nahiv ilmi: Arapça cümle yapısı ve kuruluşunun öğretildiği bir ilim dalıdır. Nahiv ders kitapları ${ }^{22}$ olarak okutulan belli başlı kitaplar ise el-Avâmilu I-Mie, ${ }^{23}$ el-Misbâhh, ${ }^{24}$ el-Kâfiye, ${ }^{25}$ Elfiye-i ibn Mâlik, ${ }^{26}$ Molla Câmii, ${ }^{27}$ Muğni'l-Lebīb ${ }^{28}$ şeklindedirler.

Belâgat ilmi: Arap dilinin düzgün ve yerinde konuşma sanatının inceliklerinin öğretildiği ilim dalıdır. Belâgat ders kitapları olarak okutulan belli başlı kitaplar ise Miftâhu I-Ulūm, ${ }^{29}$ Telhīsu I-miftâh, ${ }^{30}$ el-Mutavvel, ${ }^{31}$ Muhtasaru 'I-Meâni, ${ }^{32}$ izâh-i Me'âni i3 şeklindedirler (Sprenger, 1878; Baltacı, 1976; Bilge, 1984; Hazer, 2002; Şanal, 2003; Demir, 2005; Hızlı, 2008; Can, 2010;).

Görüldüğü üzere Osmanlı medreselerinde okutulan ve yukarıda zikredilen çeşitli ilim dallarına ait olan Arapça gramer kitapların konuları, genellikle ilk olarak ana hatlarıyla ele alınıp daha sonra izlenen ileri kitaplarda biraz daha konular açıklanarak daha ayrıntılı bir şekilde işlendiği tümevarım metodunun uygulandığı söylenebilir (Can, 2010; Usta, 2012).

\section{SONUÇ}

Osmanlı Devleti dine dayalı olarak uyguladığı eğitim ve öğretim sistemindeki temel unsur olan Kuran, Sünnet ve her ikisinden çıkarılan hükümlerin öğretildiği ilk medrese olarak Peygamber zamanında kurulan ehli Suffe'den esinlenerek, yaşamış oldukları zamana ve mekâna uygun olan şekilleri ile eğitim kurumları olan medreseleri inşa etmiştir. Eğitim ve öğretimin sağlandığı medreselerde araştırmamızın konusu olan Arap dili, günümüzde bildiğimiz yabancı bir dilin öğrenimi için hedeflenen dört temel beceri içinde yer alan okuma ve anlama, yazma, dinleme ve konuşma becerilerin kazandırılması söz konusu olmamıştır. Bilakis i̇slami ilimleri anlayabilmek için zorunlu tutulan ulumu cüz'iye ilmi adı altında öğrencilere verilen Arapça dersi genellikle sarf (morfoloji), nahiv (sentaks) ve belâgat (retorik) ilimlerine dair yazıımış olan Arapça eserler okutularak Arap dili öğretilmeye çalışılmıştır. Her ne kadar konuşmaya yönelik bir Arap dili öğretimi olmasa da medreselerde öğrencilerden istenilen ve gerçekleşen okuma ve anlamanın yanı sıra, sözlü anlatımın da gerçekleştirildiği göz önünde bulundurulmalıdır. $O$ zamanın şartlarına göre hem Arap dilinde yazılmış eserleri anlayabilecek hem de Arapça kitaplar yazabilecek seviyede kişilerin mezun olması ve günümüze kadar yazdıkları eserlerin ulaşması, almış oldukları Arapça eğitimin ne derece kuvvetli olduğunun bir kanıtı olsa gerektir.

\footnotetext{
${ }^{22}$ Nahiv kitaplarından Avâmil ve i̇zhâr adlı eserler, Osmanlı âlimlerinden birisi olan İmam Birgivi'nin, modernleşme ve yenileşme dönemi olan Tanzimat (1839)'tan sonra Osmanlı medreselerinde ders kitabı olarak okutulmuştur (bkz. Hazer, 2002).

${ }^{23}$ Eserde amiller lafzi ve mânevi olmak üzere iki gruba bölündükten sonra lafzi amiller kıyasi ve semai olarak ikiye ayrılmıştır. Semai amiller doksan bir, kıyasiler ise yedi, maneviler iki olmak üzere toplam 100 amil son derece veciz ve ihatalı olarak ele alınmıştır (bkz. Durmuş, 1991).

${ }^{24}$ Bu eserde nahiv terimleri, lafzi ve kıyasi amiller, semai ve manevi amillerin yer aldıği bir ders kitabıdır (bkz. Çöğenli, 2006)

${ }^{25}$ Bu eserde Kelimenin üç çeşiti olan isim, fiil ve harf detaylı bir şekilde anlatılmaktadır (bkz. Kılıç, 2001).

${ }^{26}$ Arap dilbilgisi kurallarının öğretimini kolaylaştırması ve hafızalarda kalıııığı sağlaması düşünüldüğünden şiir formunda yazılmış bir eserdir (bkz. Bahşi, 2013)

${ }^{27}$ Bu eser, ders kitabı olan el-Kâfiye'nin bir şerhidir. Konu içeriği ise, Kelime ve kelamdır (bkz. Arslan, 2008).

${ }^{28} \mathrm{Bu}$ eserde konu olarak edatlar, cümle ile ilgili hüküm, kural, yorum ve tahliller özgün bir yöntem izlenerek düzenlenmiş olup ayrıca sarf konuları, fonetik, belâgat, kısmen lehçe farklııkları ve tefsire dair bazı konular üzerinde de durulmuştur (bkz. Özbalıkçı, 2005).

${ }^{29}$ Bu ders kitabında hem kelimelerin teşekkülü, kalıp ve vezinleriyle iştikak konusu hem de Arap dilinin söz dizimi kuralları ve sebepleri, ayrıca belâgatın temel meseleleri anlatılmaktadır (bkz. Benli, 2005).

${ }^{30}$ Telhīs adı altında da tanınan bu ders kitabı, fesahat ve belâgat kavramlarının tanımını, kısım ve şartlarını, şiir çalıntıları meselesini ve edebî bir parçanın giriş-gelişme-sonuç bölümlerini kapsayan kompozisyon tekniğine dair temel bilgilere yer verilmiş bir eserdir (bkz. Durmuş, 2002).

${ }^{31}$ Bir önceki ders kitabı olan Telhīsu l-Miftâh kitabında bulunan kapalı hususlar açıklanmış ve onda bulunmayan bazı bilgilerin eklenerek konuların daha iyi anlaşılır biçimde anlatıldı̆̆ı bir kitaptır (bkz. Benli, 2005).

32 Bu kitap, el-Mutavvel adlı bir önceki ders kitabın kısaltmasıdır (bkz. Benli, 2005).

33 Belâgat ders kitaplarından olan Telhīsu I-Miftâh adlı kitabın ilk şerhi olan Izâhi I-Meâni adlı kitapta konular daha açıklayıcı bir şekilde ele alınmıştır (bkz. Durmuş, 2002).
} 


\section{KAYNAKLAR}

Adıvar, A. (1943). Osmanlı türklerinde ilim. İstanbul: Maarif Matbaası.

Akgündüz, H. (1997). Klasik dönem osmanlı medrese sistemi. İstanbul: Ulusal Yayınlar.

Arslan, i. (2008). Abdurrahmân el-câmî ve el-fevâidü'z-ziyâiyye adlı eseri. (Yayımlanmamış doktora tezi). Dokuz Eylül Üniversitesi, İzmir.

Aşıkpaşazâde (1332). Tevârih-i âl-i osman. İstanbul: Ali Bey Neşri.

Bahşi, T. (2013). Nahiv öğretiminde manzûm eserler "ibn mâlik'in el-elfiyye'si örneği”, Ümit Güneş. II. Türkiye Lisansüstü Çalışmalar Kongresi Bildiriler Kitabı - V Cilt. Isparta, 12-15 Mayıs 2016, İstanbul s. $233-250$.

Baltacı, C. (1976). XV-XVI. asırlar osmanlı medreseleri. İstanbul: Irfan Matbaası.

Benli, M. S. (2005). MiFTÂHU'I-ULÔM. http://www.islamansiklopedisi. info/dia/pdf/c30/c300015.pdf (Erişim Tarihi: 2017, 23 Ocak).

Bilge, M. (1984). IIlk osmanlı medreseleri. İstanbul: İstanbul Üniversitesi Edebiyat Fakültesi Yayınları.

Brockelmann, C. (1943-1949). Geschichte der arabischen litteratur. Leiden: Brill.

Can, B. (2010). Tanzimat öncesi osmanlı medreselerinde arapça öğretim yöntemleri. Ekev

Akademi Dergisi. 44, 308-309.

Çakır, M. (1992). BiNÂÜ'I-EF'ÂL. http://www.islamansiklopedisi.info/dia/ pdf/c06/c060135.pdf (Erişim Tarihi: 2017, 29 Ocak).

Çöğenli, M. Sadi (2006). MUTARRizî. http://www.islamansiklopedisi.info/ dia/pdf/c31/c310246.pdf (Erişim Tarihi: 2017, 29 Ocak).

Demir, H. (2005). Die osmanischen medresen. Frankfurt am Main: Peter Lang Verlag.

Demirayak, K. (2003). el-MAKSÛD. http://www.islamansiklopedisi.info/dia/ pdf/c27/c270324.pdf (Erişim Tarihi: 2017, 29 Ocak).

Demirayak, K. (2004). MERÂHU'l-ERVÂH. info/dia/pdf/c29/c290109.pdf (Erişim Tarihi: 2017, 29 Ocak).

Doğan, R. (1997). Osmanlı eğitim kurumları ve eğitimde ilk yenileşme hareketlerinin batılılaşma açısından tahlili. Ankara Üniversitesi Ilahiyat Fakültesi Dergisi. 37, 407-442.

Durmuş, i. (2002). KAZVîNî, Hatîb. http://www.islamansiklopedisi.info/dia/ pdf/c25/c250105.pdf (Erişim Tarihi: 2017, 23 Ocak).

Durmuş, i. (1991). el-AVÂMiLÜ'I-MiE. http://www.islamansiklopedisi.info/ dia/pdf/c04/c040102.pdf (Erişim Tarihi: 2017, 23 Ocak).

Eliaçık, M. (2014). Osmanlı medreselerinde öğretilen belâgat kitapları. Ulakbilge. 2/4. 31-39

Faroqhi, S. (1973). Social mobility among the ottoman ulema. International Journal of Middle East Studies. 4, 211.

Hazer, D. (2002). Osmanlı medreselerinde arapça öğretimi ve okutulan ders kitapları. Gazi Üniversitesi Çorum Ilahiyat Fakültesi Dergisi. 1, 274-293.

Hızlı, M. (1998). Bursa medreseleri. İstanbul: İz Yayınları.

Hızlı, Mefail (2008). Osmanlı medreselerinde okutulan dersler ve eserler. Uludağ Üniversitesi ilahiyat Fakültesi Dergisi. 17, 25-46.

insanoğlu, E. (1998). Osmanlı eğitim ve bilim müesseseleri, Osmanlı Devleti ve Medeniyeti Tarihi. 2, 227.

Inalcık, H. (1973). The ottoman empire, the classical age 1300-1600. London: Weidenfeld \& Nicholson.

İzgi, C. (1997) Osmanlı medreselerinde ilim. İstanbul: İz Yayınları.

Kılıç, H. (2010). eş-ŞÂFiYE. http://www.islamansiklopedisi.info/dia/pdf/c38/ c380144.pdf (Erişim Tarihi: 2017, 22 Ocak).

Kılıç, H. (2001). el-KÂFiYE. http://www.islamansiklopedisi.info/dia/pdf/c24/ c240092.pdf (Erişim Tarihi: 2017, 22 Ocak).

Kunter, H. ve Ülgen, S. (1938). Fatih camii. Vakıflar Dergisi. 1, 91. 
Kut, G. (1998). Anadolu'da türk edebiyatı. Osmanlı Devleti ve Medeniyeti Tarihi. 2, 21.

Özbalıkçı, M. R. (2005). MUĞNi'I-LEBîB. http://www.tdvislamansiklopedisi. org/dia/pdf/c30/c300258.pdf (Erişim Tarihi: 2017, 22 Ocak).

Özel, A. (2013). ZENCÂNÎ, İzzeddin. http://www.islamansiklopedisi.info/dia/ pdf/c44/c440155.pdf (Erişim Tarihi: 2017, 22 Ocak).

Özen, Ş. (2008). SADRÜŞŞERÎA. http://www.islamansiklopedisi.info/dia/pdf/ c35/c350306.pdf (Erişim Tarihi: 2017, 19 Ocak).

Parladır, S. (1987). Medrese hakkında pedagojik bir değerlendirme. Dokuz Eylül Üniversitesi ilahiyat Fakültesi Dergisi. 4, 173.

Saray, M. (1987). Türk dünyasında eğitim reformu ve gaspıralı ismail bey. Ankara: Türk Kültürü Araştırma Enstitüsü.

Sevinç, N. (1991). Osmanlının yükselişi ve çöküşü. İstanbul: Burak Yayınevi.

Sprenger, A. (1878). Die schulfächer und die scholastik der muslime. Zeitschrift der Deutschen Morgenländischen Gesellschaft. 32, 1-20.

Şanal, M. (2003). Osmanlı devleti'nde medreselere ders programları, öğretim metodu, ölçme ve değerlendirme, öğretimde ihtisaslaşma bakımından genel bir bakış. Sosyal Bilimler Enstitüsü Dergisi. 14, 149-168

Şeşen, R. (1986). Osmanlılar döneminde arap dili ve edebiyatı öğretimi. Studies on Turkish-Arab Relations Annual. 267.

Tahir M. (1333). Osmanlı müellifleri. İstanbul: Matbaa-i Amire.

Karakök, T. (2013). Yükseköğretim kurumu olarak osmanlı'da medreseler: bir değerlendirme. Bartın Üniversitesi Eğitim Fakültesi Dergisi. 2, 218.

Tekindağ, Ş. (1973). "Medrese dönemi”, cumhuriyetin 50. yılında istanbul üniversitesi. İstanbul: İstanbul Üniversitesi Edebiyat Fakültesi.

Usta, ì. (2012). Medreseler ve ilahiyat fakültelerindeki arapça öğretiminin temel dinamikler bağlamında değerlendirilmesi. The Journal of Academic Social Science Studies. 5/4, 263269.

Uzunçarşılı, i. H. (1965). Osmanlı devletinin ilmiye teşkilatı. Ankara: Türk Tarih Kurumu.

Yakuboğlu, K. (2006). Osmanlı medrese eğitimi ve felsefesi. İstanbul: Gökkubbe Yayınları. 


\section{SUMMARY}

It is very important to teach and learn Arabic language in order to understand commandments and prohibitions of Koran, the holy book of Muslims, sent by God to Muhammed, the last prophet. About teaching and learning of these commandments and prohitibions, this madrasa named Suffa built near Mescid-i Nebevi in Medina claimed its place in history as the first educational establishment. These kind of establishments regarded as the most outstanding education and trainin instutions of the Islamic history increased in number and represented various levels of education after the primary school though they developed within borders of Turk-Islam regions. Madrasa has a special meaning as they were allocated for education and training facilities and had relevant necessary equipments Madrasas enabled new educational establisments to be opened for the teach of Islamic sciences within certain patterns of rules outside house of worships. Turks once learning Islamic religion from dervishes who generally dealt with mystical aspect of this religion other than being religious scholars, started adopting religious requirements from book in madrasas and in connection performing commandments of the religion. However, Turkmen who were nomads adopted this religion by focusing on its emotional as well as its formal and superficial aspect and they tried to sustain their religious life according to their old Turkish beliefs. In this respect, one of the greatest states established by Turks who adopted Islam, Ottoman Empire made education and training possible in Arabic language in Madrasas which were one of the educational establishments of the instutionalization and transitional period of the Ottoman from a tribe to a principality, from a principality into a state. Ottoman Empire formed a specific education and training. The fact that Ottoman Empire attached importance to scientific issues and scientists, the educational etablishments were then free, the need of pupils for sheltering were met enabled scientific life to advance and become popular in a short span of time as well as encouraging Ottoman society in terms of education and training. In this context, Arabic language turned into a compulsory language to teach in Madrasas which were the educational establishments of that period, for the purpose of training pupils in fundamental Islamic and rational sciences after the conquest of Istanbul. The innovation in education and training incresaed the level of education in madrasas, enabled them to develop and increase in number. After some time, Ottoman Empire claimed its place in history as it had the most advanced educational establishment. The first madasa was built in Iznik in the first half of the XIV century, $1330-1331$ (h. 731/m). We do not have much information about how the educational activities were carried out before this madrasa was built by the seccond ottoman emperor Orhan. But the wide view is that the education was before done in mosques and psmall prayer rooms. Afterwards, when we look at historical resources and others reflecting socio- economical and sociak structure of that period, it is certain that qualified staffs required by the Ottoman Empire were hired from the cities of Great Seljuk Empire regarded once as the cultural center and from other rooted Islamic towns. These education and training instutions as we can say offer a similar education to current universities at that time. Educational books regarded as scientific works in these madrasas were written in Arabic language. This situation made teaching and learning of this language indispensable. This study therefore made some points about the teaching of Arabic language in Ottoman Madrasas by focusing on educative and training methods as well as the structure of madrasas and dimensions of the ducation and training activities. 